understandably petrified young man with new confidence (see previous page). Close at hand on his desk were a stethoscope with new diaphragm attachment, a sphygmomanometer, and a microscope. The consultation-the constant central episode of medical practice-included a whole new technology undreamt of a century earlier. The relation and balance of power between physician and patient were subtly altered, but we have yet to learn much about the history of this change. The social history of the consultation, and the influence, for example, of white coats, diagnostic equipment, and laboratory data on the attitudes of doctors and the expectations of patients, are fascinating and a scarcely explored territory in the history of medical practice. ${ }^{2}$
The illustration on the previous page and others throughout this issue were reproduced by kind permission of the Wellcome Institute Library.

\section{References}

1 Anonymous. Difficulty of making distinctions amongst surgeon-apothecaries. Lancet 1830 ;ii:429-32.

Reiser SJ. Medicine and the rise of technology. Cambridge: Cambridge University Press, 1978. This is an excellent account of the history of many aspects of the influence of medical technology.

${ }^{3}$ Jewson ND. The disappearance of the sick-man from medical cosmology, 1770-1870. Sociology 1976;10:225-44.

\title{
A son is killed
}

\author{
M COLEBROOK
}

Our wedding anniversary was a warm and sunny Sunday in August. The family was gathering for lunch although Nic, our Leeds medical student son, had not yet returned from a run on his motorcycle after lavishing tender loving care on his pride and joy the previous day. The meal was early so we had hardly noticed his absence. Then we saw a policeman walking up the drive. "Who has been misbehaving now ?" was the jocular reaction among us. I welcomed him in the usual affable manner, but there was no smile in return. He said that a motorcyclist had had an accident a few miles away and papers found on the machine showed that it was Nic's. The faint hope was implied that the rider was someone who had stolen it rather than Nic himself. But we knew that Nic kept his documents in his pocket so it had to be he who was, as the constable said, "critical" in the local hospital.

I left the family attempting to eat lunch and drove to the accident and emergency department. A junior nurse was detailed to talk to me, the anxious relative, while I waited. Poor girl, she did not know what to say, but I was able to chat her along as my mind went into a verbose and almost schizoid detachment from the main issue. Soon the orthopaedic consultant on call came to speak to me. His manner rendered the details of his news superfluous. "Fixed dilated pupils, severe brain damage, on a ventilator. I have to say that the outlook for survival is not good. Police escort to Queen's Square has been arranged. Would you like to see him ?" All said with utmost sympathy but the message was clear. I entered the resuscitation room. It was Nic all right but far from being all right. All the technical hardware had been attached and the ambulance was waiting. I mumbled my thanks to the young multiracial team that had done their utmost for my son and went home.

\section{Gradually fading hope}

My wife and I drove to London thankful that Sunday meant light traffic and easy parking once we had located the National Hospital for Nervous Diseases in a frustrating maze of one way streets. We sat in the ward waiting room. The houseman came and said that the outlook was poor, then the senior registrar, equally pessimistic but more authoritatively so. The computed

\section{Bedford, Bedfordshire}

M COLEBROOK, $\mathrm{MB}, \mathrm{BCHIR}$, general practitioner

Correspondence to: 2 Goldington Road, Bedford, Bedfordshire MK40 3NG. tomography scan showed gross cerebral contusion with blood in the ventricles, so the hope of a nice drainable haematoma vanished. He offered to bring in the consultant but I saw no point. The case was straightforward; straightforwardly bad. We said that Nic and we had agreed when he first went motorcycling that his kidneys and any other useful organs should be made available if he died. Then we entered the ward and sat beside him. There was even more apparatus than before yet he simply looked asleep. His skin was unmarked, warm, and pink, and his chest moved with the ventilator. The nurses attending him talked to him, evidently well briefed in the fact that hearing may be present even in the absence of all response. They tried hard to raise our hopes after the doctors' foreboding.

That evening his girlfriend arrived and she and my wife sat up with him all night while I went home and returned the next day with his elder brother. There was no change, only the news that blood had been taken for tissue typing. The implication did not escape us. We went out for a walk and toyed with a token lunch while he was reassessed. On our return we were told unequivocally that there was no hope of survival and I was invited to examine the findings myself. I appreciated the offer but declined with thanks. I was a father, not a doctor, just then. The surgeon from the renal unit at St Mary's was on his way. We sat beside the body that was our beloved son, brother, and boyfriend. There was an uncanny feeling about the scene. A few minutes earlier Nic was at least in one sense alive and there was hope. Now, although nothing had changed, he was dead and there was no hope. Yet so many signs of life continued, heart beat, colour, respiration, albeit by ventilator, and warmth, although we noticed that his body was being allowed to cool.

The transplant surgeon arrived. He was very kind and said that there was an acute shortage of corneas as well as kidneys. We asked him to arrange for anything of value to be taken and said that we had no hang ups about beating heart donors. Keep him going for as long as would be useful. I signed the appropriate piece of paper and we went to say goodbye to our Nic. We made ourselves realise that all was not hopeless. Somewhere out there two people in renal failure would have the hope of their lives fulfilled and two who were blind would see. I wanted to say a few words of tribute and Christian hope over him, but all I could force out with rapidly vanishing self control was the wish that those who lived with his kidneys and saw through his eyes might lead long and happy lives. Then, for the first time since childhood, my carefully cultivated composure disintegrated and I wept loudly and openly and cared not who heard and saw. My wife managed better and said a prayer of thanks for his life over him. We thanked the nurses, collected a pathetic bundle of clothes, and went home. 


\section{Shared grief and affection}

We broke the news to those at home and then started telephoning. We found that we wanted to tell family and friends but it was hard to know what to say. For the time being our grief was overruled by the task of finding words that were not callously blunt yet not too circumlocutory. Then we discovered that we were attempting to console those who were trying to console us and that there was no consolation, only shared grief and affection. At the end of that first evening we sat quietly with a few of Nic's friends and read the lines of Laurence Binyon: "They shall grow not old ... we will remember them." That was helpful in that the words said exactly part of what we felt. Finally that day came the night of weeping. I remember calling into the darkness the words of King David in the Old Testament, using Nic's name: "Oh Absalom, my son, would God I had died for thee.",

The next few days were occupied by various activities and the expression of a whole range of emotions including unashamed weeping when thinking about Nic and describing the last hours at the hospital. I was surprised at finding how very much I wanted to perform irrational rituals. My eldest son drove me to the scene of the accident so I could place a flower there with a piece of rough wood with "Nic" painted on it. Then I lay down in the ditch and bawled until my son helped me to the car. I wondered what the passer by walking his dog thought. I went to see the smashed motorcycle and left a flower on it. Weeping, I was taken by the garage manager to his office and given coffee. I apologised and said that his job was mending broken vehicles rather than broken hearts but that the two must often go together. At the funeral I followed another ritual and threw Nic's keys into the grave. I could not resent the machine that brought about his death as it had meant so much to him and was so much part of him that to hate it would be to hate him. I was thankful, however, that it was an insurance write off as it would have been hard to have the machine back repaired but not Nic.

Through the grief the delightful and the ludicrous came with welcome relief. There was the moment of incredulous ecstasy when Nic's young brother received acceptance at Leeds Medical School and the pure farce at the end of the visit from the minister of our church. We were sitting with heads bowed for a concluding prayer when the window cleaners arrived. The clatter of ladders being placed over the front window precipitated a pandemonium of double canine fury from the until then suitably reverent animals. Fortunately, our minister knew us well and he is a robust soul so prayer stedfastly continued. We found that the dogs imposed their own brand of normality that was very welcome.

The reporter from the local paper came. We liked him and our trust was justified although we were rather taken aback by the picture and the leading headlines on the front page and newsagents' boards: "Bedford doctor's son killed in motorcycle smash." Nevertheless, we took the interest in us to represent the concern of the local community. This was followed by a cascade of cards, letters, and flowers.

\section{Amazement rather than grief}

The funeral was an occasion for arrangements and astonishment rather than the display of grief. Details of plans for the services both at the church and at the grave had to be agreed and at least token hospitality organised for an unknown number of visitors. We were amazed that our son and our family could produce a church packed by so many from so far, and attract so many floral tributes and moving messages and so much in gifts to a national charity as an alternative to flowers. We discovered that the leather jacketed façade of Nic's unlikely looking motorcycling friends only thinly covered much affection and sentiment. In response to our wish the theme of the service was of positive thanks for his life. We saw no point in a negative ritual of loss nor in emphasis on an eternity that seemed a long way off.

Going through his effects was an interesting as well as a moving experience. I feared it would be distressing but there was a real delight as I found myself getting to know him in a new way after death even though I do not think that I had neglected him before. Joy and grief were present together as souvenirs of childhood rekindled memories of happy days. Letters from girlfriends certainly showed that he was appreciated and together with various literature provided a mildly educational insight into the lifestyle of young people. His student notes illustrated the intensity of modern medical training. We were thrilled to find the Leeds Medical School magazine in which he had had an essay on hepatocytes published. He had mentioned it but never shown it to us. We looked among our own belongings for tangible memories and were especially delighted to find we had kept the Christmas, birthday, and Mother's Day cards that he had given us during the year. We shall put them up at each anniversary for the rest of our lives.

Back to work. I think it helped that I made a point of wearing what I believe is my usual cheerful smile although I did not mind saying how I really felt when appropriate. Most consultations were comfortably routine but some were prolonged a little by condolences. One patient said that she had tried to write to me but had torn up three attempts. I felt an almost palpable bond with those whom I knew to have had recent comparable bereavements and could have spent much time discussing our respective losses. The only time I nearly faltered was when a lad came in carrying a crash helmet and I found that not only did he have asthma like Nic but also a similar pigeon chest. I had to sit quietly for a moment before calling the next patient.

What of those who wrote or visited to condole? None could console. Especially welcome were those who had known Nic and whose conversation revived memories for cherishing. We did not mind recounting the events of his death. Many did not know what to say and their remarks were sometimes inappropriate-for instance, the colleague who devoted his visit to a brief clinical discussion of the phenomena of bereavement and one or two church folk who wrote mini-sermons about blessing coming out of tragedy. True, but we would exchange a good deal of blessing to have Nic back. But we appreciated that all our friends desperately wanted to show their concern. Outstanding support came from a local girl who simply took over the housekeeping, an old college friend of my wife who looked after arrangements at home on the day of the funeral, and folk who came a week or two later as we would be weeping our way through a lonely Chinese take away in the evenings.

\section{More vulnerable but not depressed}

How do I feel? I could never have forecast my immediate reactions. I no longer weep openly and although my emotions are noticeably more vulnerable I have not become depressed. I miss Nic more than words can say and I cannot express how much the remaining youngsters mean to me. Even so, the family will never be complete again. He will never occupy his room, never take his place at table, nor sit down in our living room. I have only just begun to stop fantasising about him walking in the door as if nothing had ever happened. Do I feel guilty about condoning his motor cycling? In his early teens it was I who gave him the job of cleaning the surgery which, unforeseen by me, gave him the means to start motorcycling independently of my support. Should we have banned the machine from our home? He was an enterprising lad who would have earned money somehow and kept a bike at a friend's home. Then we would have lost him another way if not both ways. We decided to accept him with his youthful ambitions. We made clear to him the risks of motorcycling and that he would receive no financial support from us except for training and equipment for safety. Indeed, he achieved the top grade in the local training scheme and had the best of helmets even though it was pushed in by a tree stump like a thumb into an 
egg shell. We paid for car driving lessons at the age of 17 and made a standing offer of the use of a car even to take to Leeds. He would probably have refused the offer of a Rolls-Royce. Bikers are like that. I am simply thankful that there are no grounds for ill feeling about his death. No one else was hurt. He never drank when riding. His machine was found to have been in perfect condition. He had not stormed off after a family row. We were in mutual harmony as son and parents and all our memories are happy. To the last we never lost him and he died instantaneously doing what he most enjoyed.

How was Christmas? My brother came over from Australia and we had a good family gathering. We knew Nic would have us enjoy the day so at lunch we drank to his memory and celebrated as usual. Then the visitors went home, the youngsters went out, and we his parents wept in the lonely darkness. In January came his 21 st birthday. We put flowers on his grave. It seemed such a futile gift as he had little interest in them when he was alive. Our wedding anniversary this year will be a hurdle. Nic would want us to celebrate the occasion that eventually gave rise to his conception, but no doubt the day will be spent quietly. Grief has drawn us even closer and perhaps anniversaries from now on will mean more to us as times of thought and reflection instead of routine celebration.

\section{Where the answer begins}

I happen to be one of the many whose reaction to death is influenced by Christianity and non-religious colleagues may be interested in how this works. Why was the prayer of hundreds of believers for Nic's life refused? For me the answer begins where C S Lewis points out ${ }^{3}$ that the best of petitioners also had his most desperate prayer refused ${ }^{4}$ and was least comforted in his greatest need. ${ }^{5}$ I assume that we shall be united with Nic in eternity and that as our "then" is his "now" he has us with him already. The division of mankind into those destined for eternal felicity and those condemned to perpetual punishment or, at best, annihilation, seems so dependent on conflicting sectarian dogma that I am content to leave the running of eternity to that ultimate reality for which I believe Christ to be the evidence. I do not find the answers to the questions "why ?" and "why Nic?" in religion but in life. The first answer is in the counterquestion "why not Nic ?" Secondly, I discover that freedom of all kinds entails risks and that means that the worst consequence, death, is going to happen to someone some time and by random chance, not with any form of fairness. Freedom of speech, political freedom, freedom to climb mountains, to drive cars, and ride motorcycles costs lives. One of the safest places to be is in prison. We gave Nic freedom and he paid the price and our loss is our share in that cost.

\author{
References \\ ${ }^{1}$ Binyon L. For the Fallen. Collected Poems of Laurence Binyon. London: \\ Macmillan, 1931:209. \\ 22 Samuel xviii, 33 \\ ${ }^{3}$ L ewis CS. Fern-seed and elephants and other essays on Christianity. \\ London: Collins, 1975:103. \\ Mark XIV, 32. \\ - Mark XV, 34.
}

Founded by Charter of King James I on 6 December 1617, the Worshipful Society of Apothecaries is the city livery company of the medical profession and a medical licensing body; it grants a fully registrable medical qualification, and various postgraduate diplomas. The society has owned the site of its hall since 1632. Before this the hall was part of the property of the Dominican (Black Friars) Friary from 1278 until its dissolution by Henry VIII in 1539. The hall and the remaining property of the friary were destroyed by the Great Fire in 1666 and rebuilt to a design by Thomas Locke, largely as it is now, between 1668 and 1670. It is the oldest complete City livery hall and a unique example of seventeenth century architecture.

For the past 10 years the society has been considering the redevelopment of its property surrounding the hall (which had been purchased in stages over the years). Nevertheless, conditions were not right until 1980, when the Society's honorary architect, $\mathrm{Mr} \mathrm{T}$ E D Cusdin, prepared a memorandum on a comprehensive development of the society's properties. Encouraged by his opinion, the society engaged Mr Sam Lloyd as its architect and in February 1981, acting with the society's surveyors, he made proposals for the restoration, rehabilitation, and partial redevelopment of the society's property in Black

\section{Winchester, Hants}

Sir RONALD GIBSON, FRCS, FRCGP, retired general practitioner and Master, the Society of Apothecaries 1981-2
Friars Lane and Playhouse Yard (Shakespeare's Black Friars Theatre stood just south east of the great hall, and part of the site of the theatre now forms a corner of the society's property).

\section{Redevelopment}

Redevelopment was proposed in four major phases, beginning with the restoration and reinstatement of the library on the first floor. This library has a particular historic interest as it is on the site of the spring of a bridge erected in 1522 by Henry VIII when he entertained Charles V, King of Spain and Emperor of Germany. It was then called a gallery, and allegedly Catherine of Aragon, Wolsey, and Campeggio all walked through it on their way to the Parliament Chamber of the Friary, where the validity of the marriage of Henry VIII with Catherine was argued. (Scene IV of Shakespeare's Henry VIII is set in "a hall in Black Friars.")

Regrettably this lovely room had been converted into a wine dispense and the court intended to proceed with its restoration at once. This work has now been completed and the refurbished library was opened by HRH the Duke of Kent at the society's soirée on 21 July 1982. This phase also entailed rebuilding the stairway into the courtyard from the south end of the hall and refixing an existing eighteenth century panelled door into the arch at the top of the stairs.

In succeeding phases a new building is to be erected on the site to the north of the hall, the new frontage being built in a 